\title{
"Impact of corporate restructuring on the financial performance of commercial banks in Nigeria"
}

\begin{tabular}{|c|c|}
\hline AUTHORS & $\begin{array}{l}\text { Lawrence Uchenna Okoye (D https://orcid.org/0000-0001-6999-0100 } \\
\text { R https://publons.com/researcher/1897607/lawrence-u-okoye/ } \\
\text { Alexander Ehimare Omankhanlen (D https://orcid.org/0000-0002-4004-4046 } \\
\text { Johnson I. Okoh } \\
\text { Felix N. Ezeji } \\
\text { Esther Ibileke }\end{array}$ \\
\hline ARTICLE INFO & $\begin{array}{l}\text { Lawrence Uchenna Okoye, Alexander Ehimare Omankhanlen, Johnson I. Okoh, } \\
\text { Felix N. Ezeji and Esther Ibileke (2020). Impact of corporate restructuring on the } \\
\text { financial performance of commercial banks in Nigeria. Banks and Bank Systems, } \\
\text { 15(1), 42-50. doi:10.21511/bbs.15(1).2020.05 }\end{array}$ \\
\hline DOI & http://dx.doi.org/10.21511/bbs.15(1).2020.05 \\
\hline RELEASED ON & Monday, 02 March 2020 \\
\hline RECEIVED ON & Monday, 22 July 2019 \\
\hline ACCEPTED ON & Wednesday, 22 January 2020 \\
\hline LICENSE & $\begin{array}{l}(c) E Y \text { EY } \\
\text { This work is licensed under a Creative Commons Attribution } 4.0 \text { International } \\
\text { License }\end{array}$ \\
\hline JOURNAL & "Banks and Bank Systems" \\
\hline ISSN PRINT & $1816-7403$ \\
\hline ISSN ONLINE & $1991-7074$ \\
\hline PUBLISHER & LLC "Consulting Publishing Company "Business Perspectives" \\
\hline FOUNDER & LLC "Consulting Publishing Company "Business Perspectives" \\
\hline
\end{tabular}

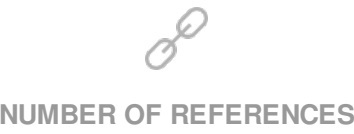

29
NUMBER OF FIGURES

0

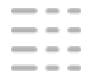

NUMBER OF TABLES

3

(C) The author(s) 2023. This publication is an open access article. 


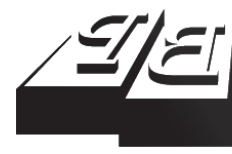

\section{BUSINESS PERSPECTIVES}

()

LLC "CPC "Business Perspectives" Hryhorii Skovoroda lane, 10, Sumy, 40022, Ukraine www.businessperspectives.org

Received on: $22^{\text {nd }}$ of July, 2019 Accepted on: $22^{\text {nd }}$ of January, 2020 Published on: $2^{\text {nd }}$ of March, 2020

(C) Lawrence Uchenna Okoye, Alexander Ehimare Omankhanlen, Johnson I. Okoh, Felix N. Ezeji, Esther Ibileke, 2020

Lawrence Uchenna Okoye, Ph.D., Lecturer, Department of Banking and Finance, Covenant University, Ota, Nigeria.

Alexander Ehimare Omankhanlen, Ph.D., Senior Lecturer, Department of Banking and Finance, Covenant University, Ota, Nigeria.

Johnson I. Okoh, Ph.D., Lecturer, Department of Financial Studies, National Open University of Nigeria, Nigeria.

Felix N. Ezeji, M.Sc., Ph.D. Student, Department of Banking and Finance, Ebonyi State University, Abakaliki, Nigeria.

Esther Ibileke, B.Sc., Student, Department of Banking and Finance, Covenant University, Ota, Nigeria.

This is an Open Access article, distributed under the terms of the Creative Commons Attribution 4.0 International license, which permits unrestricted re-use, distribution, and reproduction in any medium, provided the original work is properly cited.

Conflict of interest statement: Author(s) reported no conflict of interest
Lawrence Uchenna Okoye (Nigeria), Alexander Ehimare Omankhanlen (Nigeria), Johnson I. Okoh (Nigeria), Felix N. Ezeji (Nigeria), Esther Ibileke (Nigeria)

\section{IMPACT OF CORPORATE RESTRUCTURING ON THE FINANCIAL PERFORMANCE OF COMMERCIAL BANKS IN NIGERIA}

\begin{abstract}
The implementation of the 2004-2005 bank capital reform in Nigeria, introduced to deepen the financial capacity of the banking system, has led to a major restructuring of the banking sector. The reform required banks to increase their equity capital by about 1150 per cent (from two billion to twenty-five billion naira) within 18 months. Due to compliance challenges, the reform formed just twenty-five out of eighty-nine banks that previously existed. More than seventy-five per cent of the banks emerged through mergers and acquisitions. However, despite the massive increase in assets and deposit growth, episodes of bank distress have remained a recurring irritant in the country's financial system. This study compares bank performance in the pre- and post-reform periods to determine the usefulness or efficacy of the capital reform in boosting bank performance based on panel analysis of data from five banks. The study covered the period 1996-2016. The generalized method of moments was used to evaluate the parameters of the model. The result of the random effects model shows a weak positive effect of total assets and deposit growth on bank performance in the pre-reform period. However, the post-reform assessment reveals that while profitability is significantly low in large-sized banks, it is higher in smaller banks. Given the above evidence, the study asserts that profit performance of banks is substantially linked to restructuring of the sector.
\end{abstract}

\section{Keywords}

reorganization, consolidation, mergers, acquisitions, recapitalization, profitability

\section{JEL Classification $\quad$ C23, G21, G34}

\section{INTRODUCTION}

Corporate restructuring is a business strategy that consciously engages and aims to affect policies, programs, products, processes, and people to serve redefined policies and programs (Sinha, 2015). It is a deliberate, important and unusual alteration in the organization and operation of business entities suffering from financial and operational crises, and it is typically associated with changes in ownership and financial structure of the firm (Coates IV, 2014). This suggests that the imperative to restructure often derives from challenges arising from dynamics of market variables and/or internal problems of management. Depending on a firm's primary motivation, corporate restructuring may take the form of changing the composition of assets by divesting from non-performing assets and increasing the stock of blue chips or divesting from those business units that are not part of its core business area, to allow the firm to concentrate on its core business for optimal performance. It can result in changes to the financing mix or financial structure, dividend and capitalization or retention policies. It can also take the form of technological or organizational changes. However, regardless of the form, organizations are restructured to maximize profitability and value for stakeholders. 
The banking consolidation program aimed to create a diversified, robust and dependable banking system that can actively support the development of the Nigerian economy and, at the same time, operate competitively in the African regional and the global financial system (Soludo, 2004). It offered a veritable platform for a major restructuring of banking business in the country through mergers and acquisitions. Under the program, banks were required to raise their equity capital from two (2) billion naira to twenty-five (25) billion naira within a period of 18 months. The short compliance period had obvious implementation difficulties for banks leading to a drastic reduction in the number of banks from 89 to 25 (Okafor, 2011). The exercise led to the fusion of 75 banks into 25 and the operating licenses of the other 14 banks that could not satisfy the recapitalization requirements were withdrawn by the Central Bank of Nigeria.

Following the successful implementation of the banking consolidation initiative in Nigeria, Sanusi (2010) explains that banking sector deposits and credits recorded a four-fold increase between 2004 and 2009, while bank assets increased by about 76 per cent on an annual basis. It was expected that the positive outcome would promote stability in banking operations and deepen the capacity of banks to support real sector growth but it did not, because despite the milestone achievement of the recapitalization exercise, episodes of bank distress remain a constant irritant in the financial system in Nigeria. Data from reviewed literature indicate that most of the Nigeria-based studies on the subject focused on post-restructuring performance of banks. We expect that comparative studies should provide a more objective performance assessment of the exercise. However, this area of research seems not to have received adequate attention. This study, therefore, examines the impact of the reform on the banking sector performance in the pre- and post-reform periods, based on a sample of five banks resulting from mergers and acquisitions. As the program aimed to strengthen the asset base of banks and restore public confidence in the system, bank size and bank deposits are used in this research to explain bank performance. This research will provide evidence-based information for executing future restructuring initiatives.

\section{LITERATURE REVIEW}

Banking consolidation derives from the concentration theory of business, which posits that as firms become larger, they are better able to diversify their operations, enhance their profitability and thereby become more resistant to shocks. This argument implies that concentration promotes stability. Proponents of the theory also argue that increased concentration drives efficiency through reduction in unit cost of service delivery. They also argue that eliminating weak or fragile businesses from the system minimizes industry risk, while several existing ones have a wider range of opportunities for more profitable diversification (Berger, 2000; Allen \& Gale, 2003). Monitoring and control of the few consolidated banks by industry regulators are thereby easier and more effective, while risk of contagion is less pronounced (Beck, Demirguc-Kunt, \& Levine, 2003).

However, critics argue that banking concentration could promote excessive risk exposure through higher debt and off-balance sheet engagements. It is also argued that concentration could produce large and complex banks, which may not be managed efficiently (De Nicolo, Bartholomew, Zaman, \& Zephirin, 2003). The theory is further criticized on the grounds that it can stifle competition, restrict access to financial services, intensify market power as well as political influence and render the system unstable when banks become too big to subject themselves to market discipline (DemirgucKunt \& Levine, 2000; Beck, Demirguc-Kunt, \& Levine, 2004; Bank for International Settlements, 2001). Critics also argue that concentration can produce strong and powerful firms that can unduly influence policy formulation and design of regulatory framework (regulatory capture) thereby compromising efficiency in the conduct of business operations.

Opinions differ on whether or not banking performance can be enhanced through mergers and acquisitions. While advocates of the concentration theory posit that mergers and acquisitions produce bigger and stronger banks that are capable of ensuring enhanced service delivery more prof- 
itably, critics argue that concentration stifles competition, promotes inefficiency and lowers profitability. In terms of empirics, research findings on how firm performance responds to changes in a corporate structure are mixed.

Oloyode and Sulaiman (2013) conducted a comparative study of the post-restructuring performance of a sample of firms selected from the banking and oil and gas sectors of the Nigerian economy. The study covered ten banks and four other firms from the oil and gas sector. Model estimation was based on the methods of ratio analysis and paired sample t-test. The study indicates that restructuring significantly impacted profitability, liquidity and solvency of firms in the real sector but not the financial sector. Olokoyo, Adegboye, Okafor, Okoye, and Akinjare (2018) also reveal a strong positive effect of mergers and acquisitions on bank performance. Based on data for 2000-2013, the study used ordinary least squares method (OLS) to estimate response of bank performance to the 2004/2005 bank capital restructuring in Nigeria.

Maimako and Oladele (2012) investigated how corporate restructuring affected shareholder value creation in the Nigerian banking sector using 21 quoted commercial banks. The study combined primary and secondary data. Primary data was collected from a randomly selected sample of 372 management staff of the banks, while relevant secondary data on the banks were gathered from their published accounts. Analytical technique based on difference of means was used to evaluate how the banks performed in the pre- and post-consolidation periods of 2000-2004 and 2005-2009 to ascertain if bank performance differed significantly between the periods. The result shows a significant impact of corporate restructuring (in the form of mergers, acquisitions, and capital restructuring) on the shareholder value creation.

Udoidem and Acha (2012) analyzed the rate at which bank assets grew in the pre- and post-reform implementation periods to ascertain how mergers and acquisitions affect bank performance. Two independent samples - pre-reform (19972003) and post-reform (2004-2010) - were analyzed. The study showed that growth in bank assets did not differ significantly between the periods.
In a related study, Okoye, Modebe, Achugamonu, and Isibor (2016) employed Levene's independent sample test to determine the extent to which the performance of banks differed between the preand post-implementation of the reform program in Nigeria but found a strong positive effect of the exercise on bank assets. The study also reported a considerable reduction in capital adequacy after the exercise. The scope of the research was extended in Okoye, Adetiloye, Erin, and Evbuomwan (2017) by introducing additional performance indicators to the model. Based on the same estimation method, the study indicated significant decrease in asset quality and capital adequacy as well as significant increase in total loan exposure in the post-consolidation period.

Okafor, Ikechukwu, and Adebimpe (2010) analyzed the post-implementation performance of Nigerian banks to ascertain the extent to which they are affected by the level of capitalization using two samples of 10 banks each. The samples were classified as weak and strong banks based on their stock market capitalization. Panel data on the sampled banks were analyzed using the Least Squares Dummy Variable Model. The study shows that bank earnings do not significantly respond to bank size, rather they are highly driven by liquidity and capital adequacy. In addition, the fixed effect model indicates that capital adequacy impact on bank performance is stronger for weak banks than for strong banks.

Muritala, Ijaiya, Adekunle, and Abidoye (2017) also studied the nexus between capitalization and performance of banks in Nigeria based on panel analysis of ten deposit money banks (DMBs) over the period 2006-2014. Estimates from the panel least squares show that bank size, bank deposits, operating expenses and bank liquidity did not significantly affect performance (measured as ROA) in the post consolidation period. The study, however, shows that post-consolidation increases in loans and advances reduced profitability in the study sample. This study, however, did not present the status of bank performance prior to the consolidation exercise in order to establish whether or not capitalization is a veritable tool for enhancing performance.

Konboye and Nteegah (2016) explored the link between bank capitalization and profitability using 
both panel and partial frontier efficiency methods. The study, covering 18 deposit money banks (DMBs), reveals that bank capital significantly affects profitability. The partial efficiency frontier estimates further show that increased bank capitalization enhanced the performance of Unity Bank (a small bank), while it retarded the performance of Union Bank (a big bank).

Ikpefan (2012) investigated the role of bank capitalization in the performance of Nigerian banks using a sample of 14 listed banks selected through stratified random sampling technique. A panel analysis of the data shows a strong positive effect of bank assets, bank loans and bank liquidity on return on capital. It, however, indicates that bank deposits have strong negative effect on return on capital. The study did not provide evidence on the pre-reform correlation between bank performance and the explanatory variables.

Oleka and Orga (2014) provided further insight into the role of consolidation in bank performance by investigating the post-consolidation performance of banks that met the bank capitalization requirements of twenty-five (25) billion naira on their own (stand-alone banks) and those that met the requirements through mergers and acquisitions. The study analyzed data from twenty-one consolidated banks for the period 20042012 , based on the technique of equality of key profitability ratio means (ROA, ROE and EPS). It reveals that the merged banks were significantly more profitable than the stand-alone banks. This suggests that restructuring based on mergers and acquisitions supports enhanced firm performance.

The work of Emori, Nkamare, and Nneji (2014) that focused on the nexus between banking consolidation and economic development in Nigeria was extended to include an analysis of the link between consolidation and bank performance. The study provided statistical evidence that bank capital and bank investment support enhanced performance.

Hakimi, Hamdi, and Djelassi (2015) investigated how banking concentration impacts profit performance among Tunisian banks. By analyzing the profit performance of a sample of nine banks between 1980 and 2009, the study showed a sig- nificant positive effect of banking concentration on the profitability of banks. Return on assets (ROA), Return on equity (ROE) and Net interest margin (NIM) were adopted as measures of bank profitability.

Anasweh (2015) examined how market structure affects banking sector performance in Qatar using a sample of thirteen banks listed on the Qatar Stock Exchange. The study covered a 5-year period of 2009-2014, and it shows that liberalization of the banking industry promotes performance through increased competition. This result implies that banking concentration is an impediment to enhanced performance.

Jeon and Miller (2002) conducted a state-by-state study in the United States of America to determine the nature of correlation, if any, that exists between concentration and bank performance. Bank share of total assets was adopted as a proxy for concentration. Both fixed and random effects models were analyzed in the study. The result shows strong positive correlation between bank concentration and performance. It also confirmed the causal impact of concentration on performance.

Zhang, Jiang, Qu, and Wang (2013) used a unique dataset from the BRIC (Brazil, Russia, India and China) banks for 2003-2010 to examine the relationship between market concentration, risk-taking and bank performance. They find that market concentration negatively correlates with bank performance. The study also confirmed negative association between risk-taking and bank performance, indicating that lower levels of risk are related to better performance.

Data from the reviewed literature indicate support for and against the concentration theory, indicating that the concentration argument is far from settled. For example, Jeon and Miller (2002), Oleka and Orga (2014), Olokoyo, Adegboye, Okafor, Okoye, and Akinjare (2018), Okoye, Modebe, Achugamonu, and Isibor (2016) and Hakimi, Hamdi, and Djelassi (2015) show that firm concentration enhances profitability while Zhang, Jiang, Qu, and Wang (2013), Okoye, Adetiloye, Erin, and Evbuomwan (2017), Muritala, Ijaiya, Adekunle, and Abidoye (2017) and Anasweh (2015) reveal 
empirical support for profitability-retarding effect of concentration. This therefore informs the imperative for further research.

\section{METHODOLOGY}

The study used historical data to explore the nexus between business restructuring and firm performance. Panel data for 1996-2016 was collected from five restructured Nigerian banks and initially analyzed with the Hausman test to determine which of its methods (fixed and random effects model) is more appropriate for the data. The Hausman test examines whether or not the unique errors or time invariant variables correlate with the regressors. The null hypothesis $(\mathrm{HO})$ for the Hausman test is that the random effect is the preferred model, while the alternative $(\mathrm{HI})$ is that the preferred model is the fixed effect. If Prob. $>$ Chi-squared is not significant ( $p>0.05), \mathrm{HO}$ is not rejected, which leads to the conclusion that the most efficient, consistent, preferred and reliable model is the random effect, but if Prob. > Chi-squared is significant ( $p=0.05$ or less), $\mathrm{HO}$ is rejected, leading to the conclusion that the fixed effect is at least as consistent and thus preferred.

\subsection{Model specification}

The following model, expressed in its explicit form, is used to estimate the response of bank performance to corporate restructuring:

$$
B A N K \text { PERF }=\beta_{0}+\beta_{1} S I Z E+\beta_{2} D G R+\mu \text {, }
$$

where BANK PERF = Bank Performance (proxied as return on equity (ROE)), SIZE = Bank capital (proxy for bank size), $D G R=$ Deposit growth rate, $\beta_{0}=$ Intercept, $\beta_{1}$ and $\beta_{2}=$ Coefficients to be estimated.

ROE measures how efficiently management uses shareholder's equity to generate earnings growth. Bank capital is estimated as total assets minus total liabilities, while deposit growth rate is a measure of successive movements in bank deposits.

\subsection{Research hypotheses}

The null form of the hypotheses formulated for this study is stated as follows:
H0: Bank capital is not better placed in large banks than in small banks.

H0: An increase in bank deposits does not profit big banks better than small banks.

\subsection{Rationale for the bank classification}

Pre-consolidation banks are classified in this study as small banks, while large banks refer to post-consolidation banks. This classification is based on the premise that all post-consolidation banks exceed their before consolidation size.

\section{RESULTS}

The results of the tests are presented and discussed as follows:

\subsection{Hausman test}

The Hausman test was used to choose which of the fixed and random effects methods of estimation best fit the model. It is based on the statistical rule that if Prob. $>$ Chi-square is not significant $(\mathrm{p}>$ $0.05), H O$ is not rejected, leading to the conclusion that the most efficient, consistent, preferred and reliable model is the random effect, otherwise $\mathrm{HO}$ is rejected and the fixed effect is accepted as consistent and preferred.

Table 1. Hausman test result for pre- and postrestructuring: $\mathrm{ROE}$

Source: Authors' computation (2018)

\begin{tabular}{l|c|c}
\hline & Pre-restructuring & Post-restructuring \\
\hline $\mathrm{Chi}^{2}(2)$ & 0.76 & 1.93 \\
\hline Prob. $>\mathrm{Chi}^{2}$ & 0.6822 & 0.3802 \\
\hline
\end{tabular}

From Table 1, the choice of the estimation method for banking performance (ROE) in the pre- and post-restructuring periods favors random effects based on the decision rule that Prob. $>\mathrm{Chi}^{2}$ is not significant $(p>0.05)$. In both cases (pre- and post-consolidation periods), $\mathrm{Prob} .>\mathrm{Chi}^{2}$ is clearly above 5 per cent, which means the non-rejection of the null hypothesis. The random effects model is therefore preferred. 
Table 2. Random effects model for pre-restructuring period

Source: Authors' computation (2018).

\begin{tabular}{|c|c|c|c|c|c|c|}
\hline ROE & Coefficients & $\begin{array}{l}\text { Standard } \\
\text { error }\end{array}$ & $z$ & $P>z$ & \multicolumn{2}{|c|}{$\begin{array}{l}\text { Confidence interval: } 95 \% \\
\text { lower and upper limits }\end{array}$} \\
\hline LSIZE & .0259776 & .0704186 & 0.37 & 0.712 & -.1120402 & .1639955 \\
\hline DGR & .1281018 & .0961332 & 1.33 & 0.183 & -.0603159 & .3165195 \\
\hline cons & .1222748 & .4638204 & 0.26 & 0.792 & -.7867965 & 1.031346 \\
\hline sigma_u & 0.0000 & \multirow{3}{*}{\multicolumn{5}{|c|}{$\begin{array}{l}\text { R-sq: } \text { within }=0.4813 ; \text { between }=0.2104 \\
\text { overall }=0.3301 ; \text { Wald } \text { chi }^{2}(2)=387.38 ; \text { Prob. }>\text { chi }^{2}=0.0000 \\
\operatorname{corr}(u, i, X)=0 \text { (assumed })\end{array}$}} \\
\hline sigma_e & .75981361 & & & & & \\
\hline Rho & 0.000 & & & & & \\
\hline
\end{tabular}

\subsection{Regression estimates}

Table 2 shows a positive impact of the log-transformed value of bank size (LSIZE) and deposit growth rate $(D G R)$ on return on equity (ROE) before the restructuring of the sector. The result indicates that an increase of 1 per cent in bank size (SIZE) will bring about an increase of 0.26 per cent in ROE, while a 1 per cent increase in $D G R$ will bring about a 0.13 per cent increase in ROE. However, these parameters do not significantly affect bank performance as shown by the probability values of their $\mathrm{z}$-statistic $(P>z)$ that fall outside the acceptance region of $0-5$ per cent.

The interclass correlation, represented as rho, indicates that 0.000 per cent of variance is due to the difference across panels. Also, the R-squared shows that 33 per cent of variations in the overall ROE model is due to changes in the explanatory variables (LSIZE and DGR). The joint impact of LSIZE and DGR on performance, shown by p-value of the Wald $\mathrm{Chi}^{2}$, is highly significant (Prob. > $\left.\operatorname{chi}^{2}=0.000\right)$. The $\operatorname{corr}(u, i, X)=0$ shows that the differences across units are not correlated with the regressors. This confirms the Hausman test assumption of non-significant correlation between the error term and the regressors, which implies that group-specific differences or characteristics of each unit do not significantly affect the overall or panel estimates.

Table 3 shows a negative impact of the log-transformed value of bank size (LSIZE) on return on equity (ROE) after the restructuring exercise. It indicates that a 1 per cent increase in bank size (SIZE) will lead to a 0.22 per cent decrease in ROE. The adverse effect of post-consolidation bank size on performance counters the pro-concentration argument. It implies that the exercise produced big and complex banks that operators could not efficiently manage, leading to sub-optimal resource allocation. This explains the observed deterioration in bank capital due to over-exposure to highrisk investments, which led to severe capital erosion in the sector and hence the introduction of the 2010 reforms (Sanusi, 2010).

The study further shows that $D G R$ positively affected ROE during the period. It indicates that a 1 per cent increase in $D G R$ will bring about a 0.40 per cent increase in ROE. This result indicates a significant increase in bank deposits after consolidation, which indicates that the restructuring pro-

Table 3. Random effects model for post-restructuring period

Source: Authors' computation (2018).

\begin{tabular}{|c|c|c|c|c|c|c|}
\hline ROE & Coefficients & $\begin{array}{l}\text { Standard } \\
\text { error }\end{array}$ & $\mathbf{z}$ & $P>z$ & \multicolumn{2}{|c|}{$\begin{array}{l}\text { Confidence interval: } 95 \% \\
\text { lower and upper limits }\end{array}$} \\
\hline LSIZE & -0.2223874 & .0987323 & -2.25 & 0.024 & -.4158991 & -.0288757 \\
\hline DGR & 0.3948811 & .1460657 & 2.70 & 0.007 & .1085976 & .6811646 \\
\hline _cons & 1.577303 & .9351004 & 1.69 & 0.092 & -.2554597 & 3.410066 \\
\hline sigma_u & 0 & \multirow{3}{*}{\multicolumn{5}{|c|}{$\begin{array}{l}\text { R-sq: } \text { within }=0.5612 ; \text { between }=0.2516 ; \text { overall }=0.4604 ; \text { Wald } \text { chi }^{2}(2)=22.21 ; \text { Prob }>\text { chi }^{2}=0.0000 \\
\operatorname{corr}(u, i, X)=0 \text { (assumed) }\end{array}$}} \\
\hline sigma_e & .96509052 & & & & & \\
\hline Rho & 0.0000 & & & & & \\
\hline
\end{tabular}


cess raised public confidence in the banking system thereby attracting more customer deposits. These parameters are shown to significantly impact ROE, as indicated by the probability values of their z-statistics $(P>z)$, which lie in the range of 0-5 per cent.

The interclass correlation, represented as rho, indicates that 0.0000 per cent of variance is due to the difference across panels. In addition, the $\mathrm{R}$-squared indicates that 46 per cent of variations in $\mathrm{ROE}$ are due to changes in the explanatory variables (LSIZE and DGR). The joint impact of LSIZE and $D G R$ on bank performance is highly significant $\left(\operatorname{Prob}>\mathrm{Chi}^{2}=0.000\right)$. The $\operatorname{corr}\left(u \_i, X\right)=0$ shows that the differences across units are not correlated with the regressors. This confirms the Hausman test assumption of non-significant correlation between the error term and the regressors, which implies that group-specific differences or characteristics of each unit do not significantly affect the overall or panel estimates.

\section{HYPOTHESES TESTING}

From the results of the random effect test, it is observed that although Table 2 shows the non-significant positive effect of bank size and deposit growth rate on bank performance before the restructuring exercise, Table 3 shows a significant negative effect of bank size as well as a significant positive effect of deposit growth rate on bank performance in the post-consolidation period. The results are evaluated based on the research hypotheses as below.

With regard to the bank size, the result indicates a significant decline in profitability despite in- creased capitalization, implying sub-optimal deployment of bank capital in the post-consolidation period. This result confirms the finding in Olokoyo, Adegboye, Okafor, Okoye, and Akinjare (2018); Konboye and Nteegah (2016); Okoye, Adetiloye, Erin, and Evbuomwan (2017). However, it contrasts with the results in Emori, Nkamare, and Nneji (2014), which presents a strong positive effect of bank size on post-consolidation performance. Also, it does not support the result of Okafor, Ikechukwu, and Adebimpe (2010); Muritala, Ijaiya, Adekunle, and Abidoye (2017), which show no significant difference between pre- and post-consolidation performance of banks.

Based on the above result, the null hypothesis (HO) is accepted for bank size, implying that bank capital is more profitably placed in small banks (pre-consolidation banks) than in large banks.

On the other hand, the strong positive effect of deposit growth rate on restructured banks' performance indicates more efficient deployment of bank deposits for profit. This result aligns with Olokoyo, Adegboye, Okafor, Okoye, and Akinjare (2018). However, it is not consistent with the result of Ikpefan (2012), which indicates a strong negative effect of deposits on bank performance, as well as Muritala, Ijaiya, Adekunle, and Abidoye (2017), which show a non-significant impact of bank deposits on performance.

Based on this result, the null hypothesis $(\mathrm{HO})$ is rejected for the deposit growth rate. This means that an increase in customer deposits enhances profitability of big banks more than small ones.

\section{CONCLUSION}

The authors estimated the response of the banking sector performance to capital reform-induced restructuring of banking operations in Nigeria to test the usefulness of the program. The generalized moment method was used in estimating model parameters. Comparing the performance of selected banks between 1996 and 2016, the random effect model shows a marginal positive effect of bank capital and deposit growth on bank performance before the banks were restructured, but in the post-reform period, these variables significantly affect banking performance. Specifically, the result indicates that banks are likely to perform sub-optimally as they grow in size. This suggests the existence of an optimum size beyond which bank capital becomes an impediment to performance. This result is in line with the views of critics of the concentration theory who argue that it could produce large and complex banks, which are likely to compromise efficiency (De Nicolo, Bartholomew, Zaman, \& Zephirin, 2003) as well as pro- 
mote excessive risk exposure. The research further reveals that high deposit growth that characterized post-consolidation banks, increases profitability of banking operations. As banks trade money, as they attract more deposits, they are better positioned to use profitable investment opportunities.

The evidence presented in the study shows that profit performance of banks differed substantially between the pre- and post-reform intervals. In view of the above result, the study thus argues that there is a strong correlation between bank restructuring and bank performance.

The study recommends that banks should sustain the deployment of customer deposits in profitable or bankable investments to support performance-enhancing potential of restructuring. In addition, the nexus between firm size and performance should be closely monitored to ensure that the balance is maintained. Finally, corporate restructuring should not be a one-off reform program as the economic and financial dynamics of the firm are likely to be a useful guide.

\section{ACKNOWLEDGEMENT}

The authors acknowledge the support of the Covenant University, Ota, in the publication of this paper.

\section{REFERENCES}

1. Allen, F., \& Gale, D. (2003). Competition and financial stability. Journal of Money, Credit and Banking, 36(3), 453-480. Retrieved from http://finance.wharton. upenn.edu/ allenf/download/ Vita/compfinstabpublished.pdf

2. Anasweh, M. S. (2015). The market concentration and banking Industry performance. Corporate Ownership and Control, 13(1), 1257-1264. http://dx.doi. org/10.22495/cocv13ilc10p11

3. Babajide, A. A., Olokoyo, F. O., \& Taiwo, J. N. (2014). Bank consolidation and small business financing in Nigeria. Proceedings of the $28^{\text {th }}$ International Business Information Management Association (IBIMA) (pp. 25222540). Retrieved from https:// www.academia.edu/12529441/ Bank_Consolidation_and_Small_ Business_Financing_in_Nigeria

4. Bank for International Settlements. (2001). The banking industry in the emerging market economies: competition, consolidation and systematic stability (BIS Paper No. 4). Basel: Bank for International Settlements. Retrieved from https://www.bis.org/publ/bppdf/ bispap04.pdf

5. Beck, T., Demirgue-Kunt, A., \& Levine, R. (2003). Bank concentration and crises (NBER Working Paper 9921). Retrieved from http://www.nber.org/papers/ w9921.pdf

6. Beck, T., Demirgue-Kunt, A., \& Levine, R. (2004). Bank concentration and fragility: Impact and mechanics (NBER Working Paper No. 11500). Retrieved from https://ideas.repec.org/p/nbr/ nberwo/11500.html

7. Berger, A. N. (2000). The integration of the financial services industry: Where are the efficiencies? (FEDS Paper No. 2000-36). Retrieved from https:// www.federalreserve.gov/pubs/ feds/2000/200036/200036pap.pdf

8. Coates IV, J. C. (2014). Mergers, acquisitions and restructuring: Types, regulation, and patterns of practice (Discussion Paper No. 781). Cambridge: Harvard Law School. http://dx.doi.org/10.1093/ oxfordhb/9780198743682.013.29

9. De Nicolo, G., Bartholomew, P., Zaman, J., \& Zephirin, M. (2003). Bank consolidation, internationalization and conglomeration: Trends and implications for financial risk (IMF Working Paper 03/158) (158 p.). Retrieved from https://www. imf.org/en/Publications/WP/ Issues/2016/12/30/Bank-Consol-
idation-Internationalization-andConglomeration-Trends-andImplications-for-16607

10. Demirgue-Kunt, A., \& Levine, R. (2000). Bank concentration: cross country evidence (Working Paper 27828). Retrieved from http:// documents.worldbank.org/curated/en/979371468780328170/pdf/ wdr27828.pdf

11. Emori, E., Nkamare, S., \& Nneji, I. (2014). The impact of banking consolidation on the economic development of Nigeria. Research Journal of Finance and Accounting, 5(16), 113-119. Retrieved from https://pdfslide.net/documents/ the-impact-of-banking-consolidation-on-the-economic-development-of-nigeria.html

12. Hakimi, A., Hamdi, H., \& Djelassi, M. (2015). Testing the concentration-performance relationship in the Tunisian banking sector. East-West Journal of Economic and Business, XVIII(2), 41-62. Retrieved from https://www.u-picardie.fr/eastwest/fichiers/art193.pdf

13. Ikpefan, O. A. (2012). Bank capitalization and performance in Nigerian banking industry (1986-2006): Empirical evidence. European Journal of Accounting, Auditing and Finance Research, 
1(4), 12-32. Retrieved from http:// www.eajournals.org/wp-content/ uploads/Bank-Capitalizationand-Performance-in-NigerianBanking.pdf

14. Jeon, Y., \& Milles, S. M. (2002). Bank concentration and performance (Economics Working Papers 200225). Retrieved from https://opencommons. uconn.edu/cgi/viewcontent. cgi?referer=https://www.google com.ng/\&httpsredir $=1 \&$ article $=12$ 80\&context=econ_wpapers

15. Konboye, L. E. J., \& Nteegah, A. (2016). Banking sector capitalization and deposit money banks' profitability in Nigeria. International Journal of Social Sciences and Management, 3(3), 203-213. http://dx.doi. org/10.3126/ijssm.v3i3.15262

16. Maimako, S. S., \& Oladele, K. O. (2012). Impact of corporate restructuring on value creation in the Nigerian banking industry. SDMIMD Journal of Management, 3(2), 77-96. https://doi. org/10.18311/sdmimd/2012/2744

17. Muritala, T. A., Ijaiya, M. A., Adekunle, A. O., \& Abidoye, M. K. (2017). Capitalization and bank performance: Evidence from Nigerian banking sector. e-Finance, 13(4), 67-75. https://doi. org/10.1515/fiqf-2016-0036

18. Okafor, C., Ikechukwu, K., \& Adebimpe, U. (2010). The effect of capital adequacy on banks' performance: Evidence from Nigeria. Journal of Business Research, 4(1-2). Retrieved from https://www.ajol.info/index.php/ jbr/article/view/69060

19. Okafor, F. O. (2011). Fifty years of banking sector reforms in Nigeria (1960-2010): Past lessons - future imperatives. Enugu: Ezu Books. Retrieved from https://openlibrary. org/books/OL25375834M/Fifty_years_of_banking_sector_reforms_in_Nigeria_1960-2010

20. Okoye, L. U., Adetiloye, K. A., Erin, O., \& Evbuomwan, G. O. (2017). Impact of banking consolidation on the performance of the banking sector in Nigeria. Journal of Internet Banking and Commerce, 22(1), 1-16. Retrieved from http://eprints.covenantuniversity.edu.ng/8195/1/BANKING\%20CONSOLIDATION\%20 \%26\%20BANKING\%20PERF_ JIBC.pdf

21. Okoye, L. U., Modebe, N. J., Achugamonu, U., \& Isibor, A. (2016). Effect of mergers and acquisitions on banking sector performance in Nigeria. $N G$ Journal of Social Development, 5(5), 78-86. Retrieved from http://m.covenantuniversity.edu. ng/Profiles/ISIBOR-AREGHAN/ EFFECT-OF-MERGERS-ANDACQUISITIONS-ON-BANKINGSECTOR-PERFORMANCE-INNIGERIA

22. Oleka, C., \& Orga, C. (2014). The impact of consolidation on the performance of banks in Nigeria - Profitability perspective (2004-2012). European Journal of Business and Management, 6(10), 47-52. Retrieved from https://pdfs.semanticscholar. org/ef0d/bf7541e3eeaae88147e7b37721906b54f632.pdf

23. Olokoyo, F. O., Adegboye, F. B., Okafor, T. C., Okoye, L. U., \& Akinjare, V. A. (2018, November 15-16). Implications of merger and acquisitions on banks' performance in Nigeria. Proceedings of the 32nd International Business Information Management Association (IBIMA). Seville, Spain. Retrieved from https://ibima.org/accepted-paper/ implications-of-merger-and-acquisitions-on-banks-performancein-nigeria/

24. Oloyede, J. A., \& Sulaiman, L. A. (2013). A comparative analysis of post restructuring performance of firms in financial and real sectors in Nigeria. Asian Journal of Empirical Research, 3(1), 62-73. Retrieved from https://ideas.repec. org/a/asi/ajoerj/2013p62-73.html

25. Sanusi, L. S. (2010, February 26). The Nigerian banking industry: What went wrong and the way forward (Lecture). Bayero University, Kano. Retrieved from https://www.proshareng.com/ report/Others/The-NigerianBanking-Industry--what-wentwrong-andthe-way-forward-BySanusi-Lamido-Sanusi/2448\#
26. Sinha, P. K. (2015). Mergers, Acquisitions and Corporate Restructuring. Mumbai: Himalaya Publishing House. Retrieved from http://www.himpub.com/documents/Chapter1158.pdf

27. Soludo, C. C. (2004)

Consolidating the Nigerian banking industry to meet the challenges of the $21^{\text {st }}$ century (Address to a special meeting of the Bankers Committee). Abuja. BIS Review, 43, 1-6. Retrieved from https://www.bis.org/review/ r040727g.pdf

28. Udoidem, J., \& Acha, I. (2012). Corporate restructuring through mergers and acquisition: Experience from Nigeria. Journal of Economics and Sustainable Development, 3(13), 135-142. Retrieved from https://www.academia.edu/3722223/Corporate_ Restructuring_through_Mergers_and_Acquisition

29. Zhang, J., Jiang, C., Qu, B., \& Wang, P. (2013). Market concentration, risk-taking, and bank performance. International Review of Financial Analysis, 30, 149-157. https://doi.org/10.1016/j. irfa.2013.07.016 